\title{
Experimental embryonic-somatic chimaerism in the sheep confirmed by random amplified polymorphic DNA assay
}

\author{
JOLANTA KARASIEWICZ*, MARIUSZ SACHARCZUK¹, BOGUSLAW WAS, ANDRZEJ GUSZKIEWICZ, \\ MACIEJ KORWIN-KOSSAKOWSKI, MARIA GORNIEWSKA, EWA SZABLISTY and JACEK A. MODLINSKI \\ Department of Experimental Embryology and ${ }^{1}$ Department of Molecular Cytogenetics, \\ Institute of Genetics and Animal Breeding, Polish Academy of Sciences, Poland
}

\begin{abstract}
Developmental potencies of sheep somatic cells (foetal fibroblasts, $\mathrm{FFs}$ ) in chimaeric animals were analysed. FFs from pigmented Polish Heatherhead (wrzosowka) breed were microsurgically injected into morulae or blastocysts of white Polish Merino breed (5 cells to each embryo). In one experiment the cells were stained with vital fluorescent dye PKH26, and chimaeric blastocysts were cultured in vitro to confirm the presence of fluorescent cells. In the majority of experiments the blastocysts were transferred to synchronized recipient ewes for development until term. Cultured embryonic cells (CEC), earlier known to produce chimaeras, were injected into blastocysts in control experiments. Seven young were born from FF-injected embryos and three were born from CEC-injected ones. All of them were white, but all three control lambs and three experimental lambs showed small areas of skin pigmentation, which indicated Heatherhead CEC or FF contribution. Tissue samples originating from three germ layers were taken from two FFsoriginating presumably chimaeric lambs (male and female) at the age of one month for DNA analysis. The random amplified polymorphic DNA-PCR method supplied two markers of chimaerism, which were amplification products of 643 bp and 615 bp long DNA fragments, found in tissues of experimental lambs as well as in FFs, but not in the blood of parents of blastocysts. The $643 \mathrm{bp}$ marker was found in the majority of tissues of both lambs. The $615 \mathrm{bp}$ amplicon was detected in the skin and lungs of the female lamb and in the hooves of the male lamb. Our data show that foetal fibroblasts introduced to sheep blastocysts can participate in development and can contribute to all tissue lineages up to at least one month of age.
\end{abstract}

KEY WORDS: sheep, chimaera, fibroblast, RAPD-PCR

\section{Introduction}

Two lines of evidence suggest that mouse somatic cells (foetal fibroblasts) can be reprogrammed to regain totipotency and to participate in embryonic development. First, experimental reprogramming of cells in vitro culminated in the results by Takahashi and Yamanaka (2006), who have shown that the four genes introduced to foetal or adult fibroblasts caused a small fraction of fibroblasts to become totipotent ES-like cells. The second line of evidence is chimaera formation after injecting foetal fibroblasts to cleaving mouse embryos (Piliszek etal.,2007). Progeny of injected somatic cells could be found in many organs of adult mice, suggesting their reprogramming in vivo and subsequent participation in development.

Mouse was the first species to give rise to experimental chimaeras (Tarkowski, 1961; Mintz, 1962). Also in the mouse (and primates) totipotent embryo-derived ES cells are available. Once injected into blastocysts these cells join to form chimaeras, and participate in all tissues of embryonic body, germ line included (Beddington and Robertson, 1989). None of these forefront heralds of easily forming adult chimaeras are available in the sheep.

Therefore we aimed at producing embryonic-somatic chimaeras in the sheep. It was ealier known that ovine embryo-derived cultured cell lines, also referred to as embryonic stem cell-like cell lines, can contribute to sheep chimaeras (Modlinski et al., 1996). In the presented experiments, such cultured embryonic cells (CECs) were injected as control, and foetal fibroblasts (Fig. 1) were

Abbreviations used in this paper:cec, cultured embryonic cell; ff, foetal fibroblast; RAPD, random amplified polymorphic DNA (assay); rs, removing sponge.

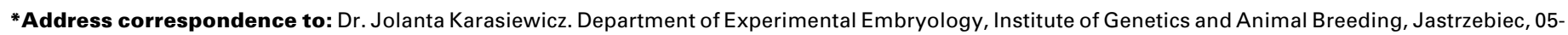
552 Wolka Kosowska, Poland. Fax: +48-22-756 14 17. e-mail: J.Karasiewicz@ighz.pl

Published online: 14 February 2008

0214-6282/2008/\$35.00

(C) UBC Press

Printed in Spain 
injected to the embryos as somatic cells. The use of RAPD-PCR assay supplied two markers of chimaerism, which allowed to confirm contribution from fibroblasts to animals born.

\section{Results}

\section{Presence of PKH26-stained fibroblasts in blastocysts}

In a single experiment observation of the embryos in vitro confirmed the presence of injected cells. The day after injection three and 5 cells were found. On the third day 2, 7 and 7 cells were found. In few cases the embryos cultured for one week displayed but one marked cell. The observations are not in disagreement with the results of detailed analysis in the mouse (Piliszek et al., 2007), showing that FFs resume divisions at day 3 after injection and that cell loses happen at any stage of development.

\section{Postimplantation development of presumed chimaeric em- bryos}

Lambing efficiency was about $12 \%$ (7 lambs out of 58 blastocysts) when presumably chimaeric blastocysts were transferred to recipient ewes (Table 1). Six transfers terminated at full term, giving rise to 7 young out of 17 blastocysts with the introduced fibroblasts (Table 2). Six lambs were perfectly normal. One (female No 5) was born dead. It was a large lamb, with shortened head. In two transfers terminated at term, 3 young were born of 4 blastocysts harbouring cultured embryonic cells. However, one lamb (male No 10) was born dead. Out of eight lambs born alive, two (female No 6 and male No 7, both originating from FFs-injected embryos) were sacrificed early (at the age of one month) to take tissue samples for DNA analysis. Of the remaining six, one (female No 9) broke leg and died. The survivors: one male and four females, grew normally and they are from two to three years old now.

\section{Overt chimaerism}

Lack of skin pigmentation and curly wool type in recipient Merino breed allows to discriminate between non-chimaeric lambs and those displaying areas of Heatherhead dark pigmented skin and slightly wavy hair that can indicate for chimaerism. These morphological features served as markers of overt chimaerism.

In the present experiments all three control lambs were born with patches of dark pigmentation on mouth and legs (Fig. 2), including male lamb $\mathrm{Nr} 10$ that was born dead and had dark patches at face and on the top of its hooves (Table 2). One female additionally had areas of donor-type hair on her legs.

Three lambs derived from FFs-injected blastocysts had at birth areas of pigmented skin (dark skin of nose and lips, some dark hair nearby, but also dark hooves; Fig. 2). At the age of about one year

\section{TABLE 1}

\section{DEVELOPMENT OF BLASTOCYSTS INJECTED WITH CELLS, AFTER TRANSFER TO RECIPIENTS}

\begin{tabular}{ccccc} 
Type of cells & $\begin{array}{c}\text { No. transfers } \\
\text { (blastocysts) }\end{array}$ & $\begin{array}{c}\text { No. term pregnancies } \\
\text { (blastocysts) }\end{array}$ & No. young born & No. live young \\
\hline FFs & $20(58)$ & $6(17)$ & $7\left(5 Q, 2 \sigma^{7}\right)$ & $6\left(4 Q, 2 \sigma^{7}\right)$ \\
CECs & $9(26)$ & $2(4)$ & $3\left(2 Q, 1 \sigma^{7}\right)$ & $2(2 Q)$ \\
\hline
\end{tabular}

CECs - cultured embryonic cells (control)

FFs - fibroblasts

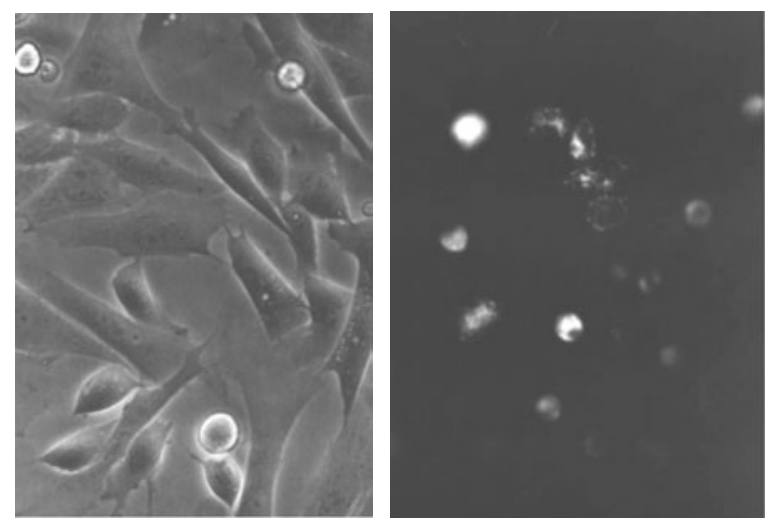

Fig. 1. Sheep foetal fibroblasts growing in vitro (left; phase contrast) and seeded after PKH26 staining (right, UV light).

the fourth lamb of this group who was white, in its general appearance resembled Heatherhead sheep (slim head, the posture), with legs covered by wavy hair. Also at the sides of the body patches of donor type hair were evident.

Two lambs with no signs of overt chimaerism (No 6 and 7) were sacrificed at 1 month of age to supply tissue samples for DNA analysis.

\section{RAPD DNA analysis}

Fourteen different tissues (blood, thymus, liver, kidney, gonads, skeletal muscles, heart muscle, small intestine, brain, skin of nose, lungs, cloven hooves, thyroid, pancreas) from lambs No 6 and 7 (a total of 27 samples) as well as samples of blood from the parents of blastocysts and the sample of the same Heatherhead fibroblasts that had been injected to blastocysts, were analysed.

Band sharing values (BS) between FFs and parents of blastocysts (Table 3 ) calculated from the electrophorograms, confirm otherwise obvious features of experimental design: high BS value between male and female parent of blastocysts reveals their

TABLE 2

\section{LAMBS BORN AFTER INTRODUCING FIBROBLASTS \\ OR CULTURED EMBRYONIC CELLS FROM HEATHERHEAD PIGMENTED SHEEP INTO BLASTOCYSTS OF WHITE MERINO BREED}

\begin{tabular}{|c|c|c|c|c|c|}
\hline No. & Sex & $\begin{array}{c}\text { Cells } \\
\text { (passage) }\end{array}$ & $\begin{array}{l}\text { Pigmented } \\
\text { skin }^{\star}\end{array}$ & $\begin{array}{l}\text { Heatherhead } \\
\text { type of hair }\end{array}$ & Comments \\
\hline 1 & Q & $\mathrm{FF}(6)$ & + & + & - \\
\hline 2 & Q & FF (4) & - & + & $\begin{array}{l}\text { Slim head and posture of } \\
\text { Heatherhead }\end{array}$ \\
\hline 3 & Q & $\mathrm{FF}(4)$ & - & - & - \\
\hline 4 & $\sigma^{\prime}$ & FF (5) & + & - & - \\
\hline 5 & Q & $F F(14)$ & + & - & Born dead, puggish head \\
\hline 6 & Q & $\mathrm{FF}(11)$ & - & - & - \\
\hline 7 & $\sigma^{x}$ & FF (11) & - & - & - \\
\hline 8 & Q & CEC (4) & + & + & - \\
\hline 9 & १ & CEC (4) & + & - & - \\
\hline 10 & $\sigma^{\prime \prime}$ & CEC (7) & + & - & Born dead \\
\hline
\end{tabular}

$\overline{\mathrm{CEC} \text {, cultured embryonic cells; FF, foetal fibroblasts; * lips, nose and/or hooves; ** legs, sides }}$ 
common breed identity (Merino), whereas lower BS values between any parent and FFs indicate other breed of the cells (Heatherhead).

In Table 4, RAPD markers identified in lambs No 6 and 7 are summarized. The majority of them ( 6 and 8 ) are type I markers, which denote bands found in any material studied (parents of blastocysts, lambs born and injected fibroblasts). Type IV marker (male parent and offspring) is only found in the female lamb, thus excluding its localization to chromosome $Y$. The absence of common amplification products for father and male lamb indicates that no $Y$ chromosome specific sequence has been revealed by RAPD analysis with the primers used.

Amplification of DNA fragments originating from donor fibroblasts, using arbitrarily chosen primers revealed the presence of two absolute RAPD markers, i.e. such that they are present only in band pattern of fibroblasts and not in DNA originating from parents of blastocysts (lambs). These markers are loci that are 615 and 643 bp long, respectively (Fig. 3). Since both bands were found in both individuals analysed (lamb No 6 and 7), thus their chimaerism has been confirmed in the form of coexistence of donor (fibroblasts) and recipient cells.

Analysis of tissue distribution (cf. Fig. 3) has revealed that all ectodermal tissues as well as tissues originating from mesoderm and/or endoderm (with the exceptions of thyroid, liver and blood) of lamb 2 (male No 7) contained marker amplification product of 643 bp long DNA fragment. Based on the quantity of this amplification product, the lamb could be characterized as showing varying tissue chimaerism. The other lamb studied (female No 6) displayed amplification product of 643 bp long DNA fragment in all tissues analysed. Also in this individual, tissuespecific variation in quantity of the product indicates for varying chimaerism (cf. Fig. 3).

The second type $\mathrm{V}$ marker was the amplification product of 615 bp long DNA fragment. The presence of this fragment was found among amplification products of DNA isolated from the skin on the nose as well as from lungs of lamb 1 (female No 6) and in DNA isolated from the hooves of lamb 2 (male No 7).

\section{Sex identification}

An accurate, sensitive, and quick method for determining the
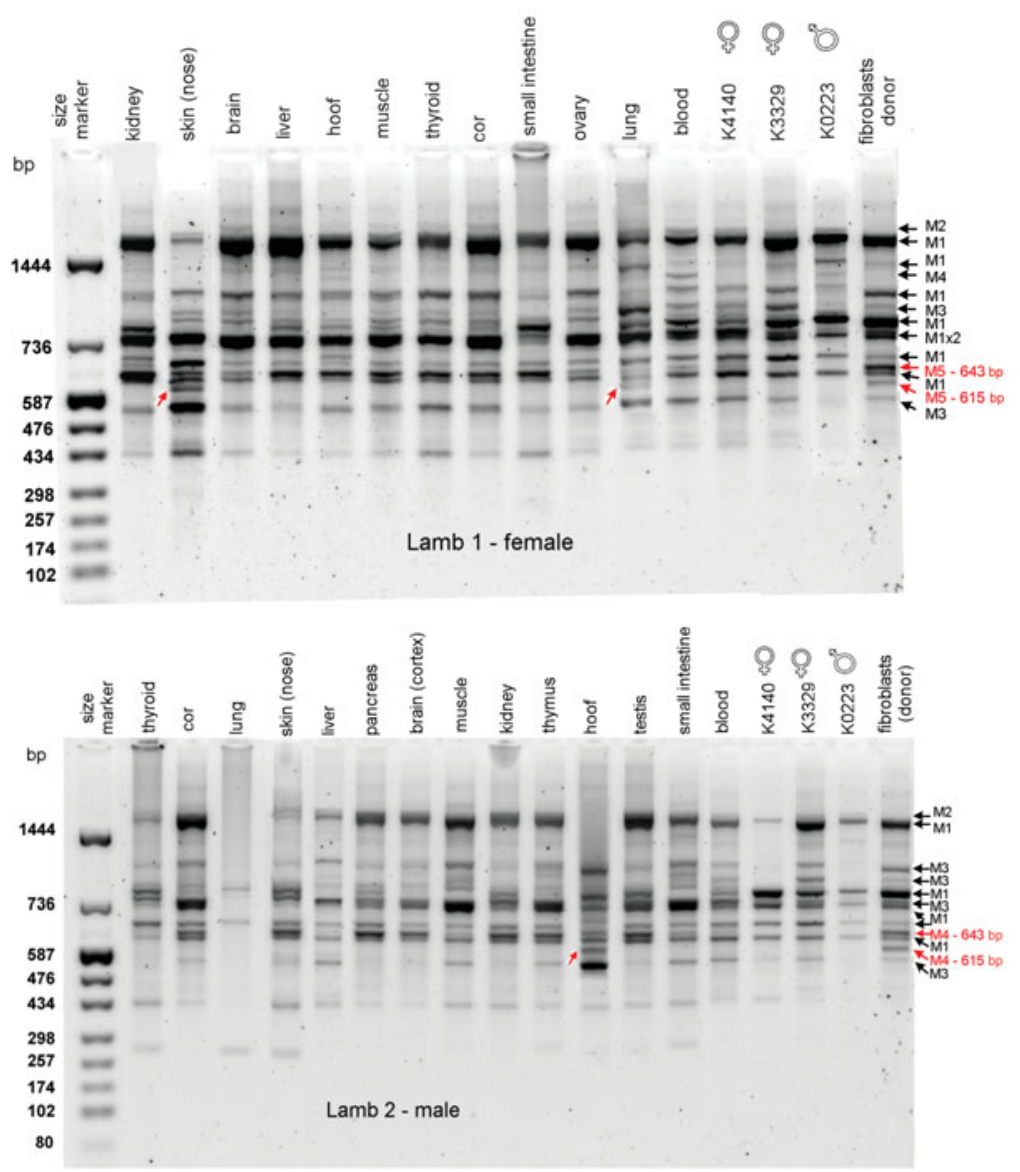

Fig. 3. Electrophorograms of RAPD molecular marker patterns generated with a primer in the tissues of the lambs as recipients, the blood of their parents (K) and in donor fibroblast cells. Two markers of chimaerism, which are amplification products of $643 \mathrm{bp}$ and $615 \mathrm{bp}$ long DNA fragments, are indicated with red arrows. In the tissue samples of the female lamb (top panel) the 643 bp marker was commonly detected. The other $615 \mathrm{bp}$ amplicon appeared in the skin and lungs. In the tissues of the male lamb (bottom panel), the $643 \mathrm{bp}$ amplicon was also omnipresent, and the $615 \mathrm{bp}$ marker appeared in the hooves. The data confirm embryonic-somatic chimaerism of the lambs at the molecular level.

sex of ovine fibroblasts consisted in using polymerase chain reaction (PCR) primers derived from an ovine-specific SRY gene (Fig. 4). The fibroblasts used in the experiments proved to be male.
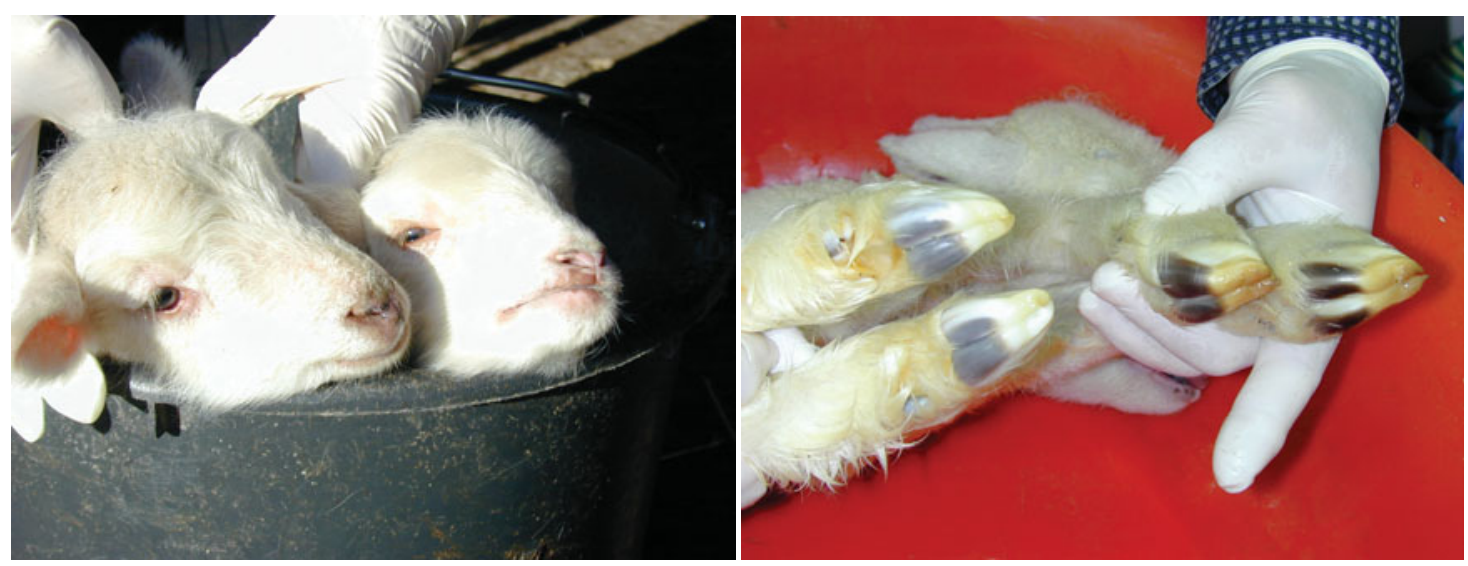

Fig. 2. Dark pigmentation of lips (lambs 8 and 9) and cloven hooves (lamb 5) is the marker of overt chimaerism, indicating the donor contribution (Heatherhead fibroblasts) to recipient blastocysts of white breed, and confirming the chimaerism of the animals. 


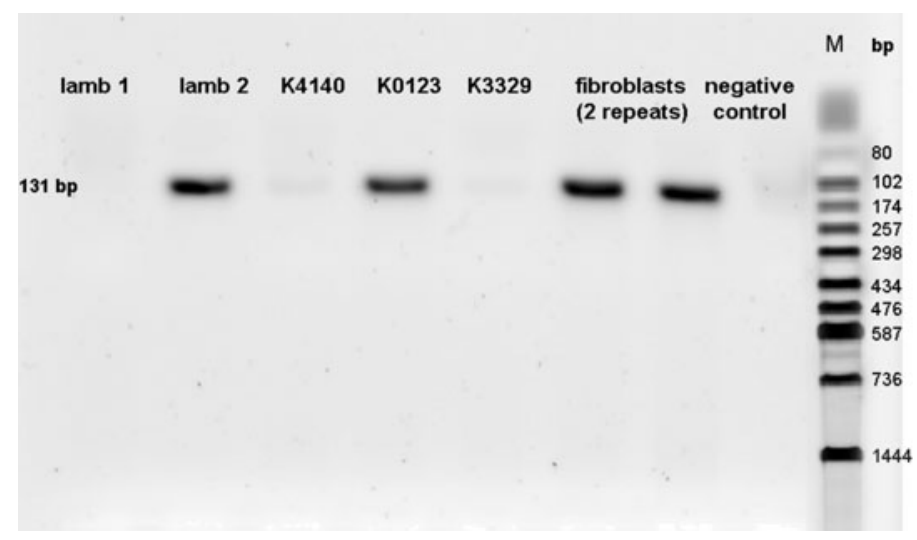

Fig. 4. Electrophorogram showing the product of ovine SRY fragment amplification (131 bp in length), as found in male parent (K0123), male lamb (lamb 2) and in foetal fibroblasts. The band was absent from female lamb (lamb 1) and female parents (K4140 and K3329). Taken together, the data are indicative of the male sex of the fibroblasts used.

\section{Discussion}

\section{Experimental chimaerism in mammals}

Mouse embryonic chimaera formation was first described by Tarkowski (1961) and Mintz (1962) and this technique spread gradually on other mammalian species. In the cow, chimaera production has been applied to rescue parthenogenetic embryos by aggregating them with fertilized ones (Boediono et al., 1999). In the sheep embryonic chimaeras were produced between cleaving embryos (Fehilly et al., 1984) and by introducing inner cell masses to blastocysts (Butler et al., 1987). Cultured embryonic cells derived from early embryos have been tested for their pluripotency by chimaera formation in many species (mouse Beddington and Robertson, 1989; cow - Cibelli et al., 1998; Iwasaki et al., 2000; Saito et al., 2003; sheep - Modlinski et al., 1996; pig - Notarianni et al., 1997; Onishi et al., 2000; rabbit Schoonjans et al., 1996; Bodo et al., 2004).

The first to test developmental potential of differentiated somatic cells by chimaera formation was Brinster (1974), who injected bone marrow cells into mouse blastocysts. In the experiments conducted later, various somatic stem cells have been proved able to contribute to foetal or adult tissue after being introduced into blastocysts (hematopoetic stem cells - Geiger et al., 1998; neural stem cells - Clarke et al., 2000; mesenchymal multipotent progenitor cells - Jiang et al., 2002; foetal somatic stem cells - Kues et al., 2005).

Foetal fibroblasts which are non-stem somatic cells, partici-

TABLE 3

BAND SHARING (BS) VALUES BETWEEN FIBROBLASTS (FFS) AND PARENTS OF BLASTOCYSTS, CALCULATED ON THE BASIS OF RAPD PROFILES

\begin{tabular}{ccc}
$\begin{array}{c}\text { Source of DNA } \\
\text { (number of bands) }\end{array}$ & \multicolumn{2}{c}{ BS } \\
\cline { 2 - 3 } & female parent/(12 bands) & male parent/(11 bands) \\
\hline FFs (11) & 0.783 & 0.636 \\
male parent (11) & 0.956 & - \\
\hline
\end{tabular}

pated in the formation of the majority of tissues in adult mice after being introduced to cleaving embryos (Piliszek et al., 2007). The mice obtained were thus adult embryonic-somatic chimaeras. In the present paper adult embryonic- somatic chimaeras are for the first time obtained in the sheep.

\section{Markers of chimaerism in the sheep}

Dark pigmentation of hooves, skin on the nose and/or lips can be used as the marker of chimaerism in white Polish Merino sheep, since pigmentation has been eliminated from this breed to such an extent, that small patches of pigmentation at birth happen to less than $0.5 \%$ lambs (Niznikowski, personal information). All three lambs born from our CECs-injected embryos, and three out of seven lambs born from FFs-injected embryos, had dark patches. This frequency is so high, that random appearance of this phenomenon can be excluded, and the skin chimaerism of these lambs can be safely concluded.

Biochemical polymorphism of glucosephosphate isomerase (GPI) has been an excellent marker of chimaerism in the mouse for over thirty years now (Chapman et al., 1972; Gearhart and Mintz, 1972a, b) and is still in use (e.g. West and Flockhart, 1994; Wang et al., 1997; Tarkowski et al., 2001; Suwinska et al., 2005). Unfortunately, isozymes of glucose-6-phosphate isomerase could not be used as the marker of chimaerism in the sheep, since two (Beatty, 1983) or three (Rasero et al., 1993) isozymes are found in each breed and there are only quantitative differences in their expression between the breeds. Therefore, for identifying molecular markers of chimaerism, random amplified polymorphic DNA (RAPD) method was used. In this method, by using a single arbitrary primer (10 mer) and amplifying DNA in polymerase chain reaction (PCR), DNA markers appear that can be separated easily on an agarose gel by electrophoresis (Williams et al., 1990). The advantages of RAPD is its simplicity, rapidity, the requirement for only a small quantity of DNA, which allows to detect small numbers of donor cells, i.e. the low level of chimaerism, and the ability to generate numerous polymorphisms (for review see: Hadrys et al., 1992; Bassam and Bentley, 1994).

RAPDs can be generated with minimal cost and investment, but the limitation is that many more dominant than codominant markers are needed to accomplish the same resolution (Huff et al., 1993) due to difficulties in distinguishing between homozygous (++) and heterozygous individuals (+-); recessive $(-)$ individuals are unambiguous. However, as soon as at least one marker of chimaerism is found, the prove of donor contribution to

\section{TABLE 4}

\section{RAPD MARKERS IDENTIFIED IN LAMBS NO 6 AND 7 (TYPE V - MARKERS OF CHIMAERISM)}

\begin{tabular}{|c|c|c|c|c|c|c|}
\hline \multirow[b]{2}{*}{ Type of marker } & \multicolumn{4}{|c|}{ Bands found in* } & \multicolumn{2}{|c|}{ Number of RAPD markers } \\
\hline & Mo & $\mathbf{F a}$ & FFs & La & Lamb $7\left(O^{x}\right)$ & Lamb 6 (q) \\
\hline 1 & + & + & + & + & 6 & 8 \\
\hline II & + & + & & + & 1 & 1 \\
\hline III & + & & + & + & 4 & 2 \\
\hline IV & & + & & + & 0 & 1 \\
\hline $\mathrm{V}$ & & & + & + & 2 & 2 \\
\hline Total & & & & & 13 & 14 \\
\hline
\end{tabular}

* Mo - mother of blastocysts; Fa - father of blastocysts; FFs - fibroblasts; La - lambs 
an individual can be accomplished. The other limitation is not always high reproducibility of the results obtained by RAPD. Unlike two-primer mediated PCR, RAPD assay is performed using low stringency conditions. By interference, mismatches may occur between the primer and its target sequence in the amplification reaction (MacPherson et al., 1993). However, with standardized methodology: the same thermal cycler, temperature profiles, the brand of DNA polymerase, and the concentration of $\mathrm{MgCl}_{2}$, primer and template DNA, we obtained a high repeatability of RAPD assay, so that the final result is reliable.

Among RAPD markers, the band patterns in the chimaeras were found to be fully additive. The offspring revealed $100 \%$ shared markers with parents of blastocysts. The presence of RAPD markers of type $\mathrm{V}$ allowed identifying chimaerism in both lambs analysed. The occurrence of such markers in band patterns indicated that fibroblasts introduced into morulae or blastocysts were able to contribute to tissues originating not only from mesoderm, which is the layer of origin of fibroblasts, but from two other germ layers as well.

Type III and IV markers are particularly important to identify the polymorphisms in RAPD loci. Sources of polymorphisms in RAPD assay may include base change within priming site sequence, deletions of priming site, insertions that render priming sites too distant to support amplification, and deletions or insertions that change the size of a DNA fragment without preventing its amplification (Williams et al., 1990).

RAPD method proved effective in the studies of farm animal species (buffalo, Indian Zebu cattle, sheep and goat) (Cushwa et al., 1996; Rao et al., 1996). However, as far as we know, RAPD has not been earlier applied to study experimental chimaerism in mammals. The effects of our attempt show that this method can possibly be used to study tissue-distribution of chimaerism and/ or transplantation efficiency.

\section{Somatic-embryonic chimaerism in the sheep}

Areas of pigmented skin in born lambs prove that somatic cells introduced to very early sheep embryos can participate in development until term. Persistant location of dark patches on mouth and legs of all lambs may suggests an ordered mechanism of somatic cell positioning in development or loosening of the morphogenetic control in distal parts of the body.

Earlier studies on embryonic goat-sheep chimaeras have shown that skin fibroblasts explanted from sites covered with goat hair as opposed to sheep wool, show chromosomal composition of the goat as opposed to the sheep, respectively (Jaszczak et al., 1999). Therefore we suggest that a lamb obtained in our study, carrying patches of unpigmented wavy Heatherhead hair, is a skin chimaera as well.

Two polymorphic DNA markers revealed a broad range of tissue chimaerism in our study, including all embryonic lineages (ectoderm, endoderm and mesoderm). From life-long cytogenetic analysis of an embryonic goat-sheep chimaera a conclusion was drawn, that cell contributions from both partners were established during primary colonization but later on they changed with the age of the animal, so that the dominant contribution increased, actually approaching $100 \%$. The exception among tissues studied was lung epithelium in which the proportion of sheep to goat cells was $1: 1$ in the 10 years old chimaera (Jaszczak et al., 1999).

Two markers of chimaerism were found in each lamb studied.
It remains to be explained why locus 615 bp long could not be found in as many tissues of lambs as the other amplified locus. A hypothesis can be offered, that loss of heterozygosity ( $\mathrm{LOH}$ ) occurs in fibroblasts introduced to embryos, causing silencing of a presumably polymorphic allel in many tissues. Indeed, LOH was detected in vitro, when mouse foetal fibroblasts at early passage were cultured for up to 24 hours (Larson et al., 2006), and can possibly occur in vivo as well

Most lambs born after receiving male fibroblasts were females. Female embryos must have been the recipients of male fibroblasts to produce female lambs. It can be further expected that gonadal chimaerism was low in at least RAPD-analysed female lamb, since normal ovary was present in this individual, contrary to what is found in embryonic $X X / X Y$ sheep chimaeras, who develop into males (Tucker et al., 1974).

Two presumably chimaeric lambs were born dead: one from the blastocyst that had obtained cultured embryonic cells (the control), and the other one after fibroblast injection. In both cases the passage of donor cells in vitro was the highest in the group. High passage might be the reason for lower vitality of the chimaeras. Even mouse embryonic stem cells, which are best suited to form germ-line chimaeras, do so most effectively, when they undergo not more than 15 passages in vitro(Fedorov etal., 1997).

In the mouse - the only mammalian species studied before somatic-embryonic chimaerism lead to the presence of hybrid cells in foetuses and the young born (Piliszek et al., 2007). The suggested origin of hybrid cells was by cell fusion of somatic cells (fibroblasts) and embryonic recipient cells. The animals were thus chimaeras between recipient cells and tetraploid hybrid cells with contributions from the donor fibroblasts. Therefore, in further studies of somatic-embryonic sheep chimaeras, cytogenetic studies and possibly also analysis of polymorphic forms of proteins should aid RAPD method.

\section{Materials and Methods}

The experiments were performed according to the rules of the Polish Governmental Act for Animal Care and were approved (No. 6/2003) by the Third Local Ethics Committee for Animal Care.

\section{Obtaining of morulae/blastocysts from hormonally stimulated ewes}

Ewes of Polish Merino breed were synchronized for 14 days with fluorogestone acetate sponges (40 mg, Chronogest, Intervet, Holland). Superovulation was induced by four injections of follicle-stimulating hormone (FSH, Sigma): $6 \mathrm{mg}$ twenty four hours before removing sponges (r.s.), $5 \mathrm{mg}$ twelve hours before r.s., $3 \mathrm{mg}$ on the morning of r.s., $2 \mathrm{mg}$ twelve hours after r.s. First signs of oestrus were observed 24 - 48 hours after r.s. Rams of Polish merino were used for natural mating starting from the onset of oestrus and then every $12 \mathrm{~h}$ until the oestrus (usually 2-4 times). Embryos were flushed from the oviducts and uterine horns at day 6-7. They were quickly transferred to warm M2 medium under paraffin oil in a Petri dish on a heated stage $\left(38.5^{\circ} \mathrm{C}\right)$.

\section{Foetal fibroblasts}

Foetal fibroblasts were derived from a 35-day Polish Heatherhead (wrzosowka) foetus. Briefly, the carcass obtained by dissecting out and discarding the soft tissues (liver, heart and other viscera) was washed in phosphate buffered saline, minced into small pieces of tissue and incubated $30 \mathrm{~min}$ in $0.25 \%$ trypsin (Sigma) at $38^{\circ} \mathrm{C}$. After adding DMEM medium (Sigma) with $10 \%$ foetal calf serum (Gibco) the suspension was centrifuged at $200 \mathrm{~g}$, and the pellet was resuspended in the culture 
medium and seeded on Petri tissue culture dishes. After the plates became confluent the cultures were expanded and cells were frozen. The appearance of these cells is fibroblastic (Fig. 1). The cells were used between the 4th and 14th passage. For the experiment the cells were thawed, and after they reached confluence, they were trypsinised out from the dish and suspended in M2.

\section{Cultured embryonic cells}

Polish Heatherhead embryonic cell lines have been produced from Day 12 embryonic discs, essentially as described earlier (Karasiewicz et al., 1996) and were cultured in Dulbecco's modified Eagle medium (high glucose: $4.5 \mathrm{~g} / \mathrm{l}$, Sigma), supplemented with $0.1 \mathrm{mM} \beta$-mercaptoethanol, $0.1 \mathrm{mM}$ nonessential amino acids, and nucleosides (Robertson, 1987 ), with $20 \%$ foetal calf serum. The appearance of these cell lines is epithelioid. The cells were used between the 4th and 7th passage. For the experiment the cells were trypsinised out from the dish and suspended in $\mathrm{M} 2$.

\section{PKH26 staining}

In some experiments fibroblasts were stained with $\mathrm{PKH} 26$ dye (Sigma) according to the manufacturer's instructions. Briefly, freshly diluted dye was added to the pellet of cells at a concentration of $2 \times 10^{-}$ ${ }^{6} \mathrm{M}$ for 2-5 $\mathrm{min}$ at room temperature. Extensive rinsing of cells with culture medium containing $10 \%$ foetal calf serum, together with three rounds of pelleting them by mild centrifugation, prevented any cell deterioration. In fact, when followed up in vitro the stained cells survived at least next two passages. The cells were red fluorescent upon the use of filter set for rhodamine, in Opton inverted fluorescent microscope IM35 (Zeiss, Germany). The same dye was earlier used to mark cow blastomeres (Rho et al., 2001).

\section{Injection of fibroblasts or embryonic cells into the embryos}

For manipulation the embryos were placed together with fibroblasts or embryonic cells in micromanipulation chamber, in M2 medium. The chamber was placed in Leitz Fluovert inverted microscope equipped with Nomarski Differential Interference Contrast under which all micromanipulation procedures were carried out. Leitz mechanical micromanipulators were used. Pipettes were pulled at P-97 puller (Sutter Instruments Ltd., USA) of $1 \mathrm{~mm}$ capillaries (Sutter Instruments Ltd., USA). Five cells were placed in the middle of a morula or within the cavity of blastocyst.

\section{Co-culture in vitro}

After manipulation the embryos were placed on Vero/BRL monolayer (Duszewska et al., 2000) or STO feeder layer to be cultured overnight (for transfer) or longer. The culture medium was DMEM, which was supplemented like for embryonic cells.

\section{Transfer to recipient ewes}

After co-culture the blastocysts (in groups of 2 to 5 ) were transferred to Heatherhead ewes, that were synchronized and $\mathrm{FSH}$-injected due to the same procedures as the embryo donors, but applied one day in advance. Pregnancy was diagnosed by ultrasonography.

\section{Tissue samples from born lambs}

Two lambs were slaughtered in the slaughterhouse of Institute of Genetics and Animal Breeding. Tissues samples were immediately taken from them and were frozen at $-70^{\circ} \mathrm{C}$ until the time of DNA isolation.

\section{DNA isolation}

Total cellular DNA from frozen tissues of recipients (lambs), from fibroblasts and blood samples of parents, was isolated using DNeasy Blood \& Tissue Kit (Qiagen, Japan) according to the manufacturer's instructions and was stored at $-70^{\circ} \mathrm{C}$. The DNA concentration and quality was measured using spectrophotometry (FT-IR BIO-RAD FTS 135; USA) (at 270, 320 and $360 \mathrm{~nm}$ ) and by electrophoresis, and the DNA samples were adjusted to a final concentration of $100 \mu \mathrm{g}$ per ml.

\section{RAPD method}

PCR reactions were performed by using $25 \mu$ of a mixture containing $10 \mathrm{mM}$ Tris- $\mathrm{HCl} \mathrm{pH} \mathrm{8.0,1.5} \mathrm{mM} \mathrm{MgCl}$, with four dNTPs (0.2 mM each), $0.2 \mu \mathrm{M}$ primers, 1.5 units of Taq DNA polymerase (Polgen, Poland) and 10 ng genomic DNA. 10-mer primer (CCBC - 5'AAACGGGCGG 3') synthesised in DNA Sequencing and Oligonucleotide Synthesis Laboratory, Institute of Biochemistry and Biophysics (Warsaw, Poland) and previously tested in other experiments was used. Reactions were carried out using DNA thermocycler (MJ Research, USA) programmed as follows: incubation at $94^{\circ} \mathrm{C}$ for $3 \mathrm{~min} ; 40$ cycles at $94^{\circ} \mathrm{C}$ for $1 \mathrm{~min}, 40^{\circ} \mathrm{C}$ for $1 \mathrm{~min} 45 \mathrm{~s}$, and $72^{\circ} \mathrm{C}$ for $1 \mathrm{~min} 30 \mathrm{sec}$, followed by one final extension cycle of $10 \mathrm{~min}$ at $72^{\circ} \mathrm{C}$. A negative control reaction omitting template DNA was prepared each time. All amplification reactions were repeated twice to test reproducibility.

\section{Fragment visualisation}

Amplified RAPD products were separated and visualized in $2 \%$ agarose gels $(20 \times 10-\mathrm{cm})$ stained with ethidium bromide, with Tris-borate (0.089 M Tris, $0.089 \mathrm{M}$ borate, $2 \mathrm{mM}$ EDTA, pH 8.3) tank and gel buffers. An additional molecular-weight marker $1444-80$ (pUC/Bsp R1/ Taq) was added in the outside lane and gel running times were set so that fragments $>80 \mathrm{bp}$ were retained on the gels.

\section{Computational analysis}

Visual analysis of the band patterns was aided by DNA-ProScan software (DNA ProScan Inc., USA). The results were derived from the analysis performed by two researchers (inter-researcher results correlation was close to 1). The analysis included only bands representing fragments ranging from 500 to 1500 base pairs (bp). Amplified DNA fragments (bands) were scored as 1 (fragment present) or 0 (fragment absent) for each sample. Banding patterns were compared between the lanes to identify shared and non-shared bands. Bands were regarded as non-shared if they differed in their position more than half of band width and if intensity ratio was less than 1:4.

\section{Statistic calculations}

Based on the results of patterns generated by RAPD the calculations were done to compare analysed individuals and to seek genetic distance between them. Major statistical parameters of band patterns, such as band sharing (BS), based on the number of common bands between two individual samples, were used to describe the similarity between profiles of RAPD. BS was estimated with the following assumptions: a) All RAPD loci show complete dominance, b) All loci have two alleles, c) The marker alleles from different loci do not comigrate to the same position on the gel. This parameter was calculated from the formula:

$$
B S=\frac{2 N_{a b}}{N_{a}+N_{b}} \text {, where } \mathrm{N}_{\mathrm{ab}} \text { is the number of bands shared and } \mathrm{N}_{\mathrm{a}} \text { and }
$$

$\mathrm{N}_{b}$ are the total number of bands scored in samples $A$ and $B$, respectively (Jeffreys and Morton, 1987).

\section{Sex identification in fibroblasts and its confirmation in lambs and their parents}

DNA was extracted from fibroblasts and from blood of parents of blastocysts and of lambs, using DNeasy ${ }^{\circledR}$ Blood \& Tissue Kit (QIAGEN $\mathrm{GmbH}$, Hilden, Germany) according to the manufacturers' handbook. Isolated DNA was diluted in $50 \mu \mathrm{l}$ distilled $\mathrm{H} 2 \mathrm{O}$ and used for further analyses.

We used one set of primers for amplifying the sheep SRY gene. The DNA sequences of the primers were:

F: 5'-CTCGTGAACGAAGACGAAAGG-3') and 
R:5'-CTGTGCCTCCTCAAAGAAATGG-3'. Amplifications were performed in a final volume of $20 \mu \mathrm{l}$ in $10 \mathrm{XPCR}$ buffer (15 mM MgCl2, $\mathrm{pH} 8.3$ ), 100 $\mu \mathrm{M}$ for each dNTP (Polgen, Lodz, Poland), with $1 \mathrm{M}$ Taq DNA Polymerase (Polgen, Lodz, Poland) and 10 pmol of each primer synthesised in DNA Sequencing and Oligonucleotide Synthesis Laboratory, Institute of Biochemistry and Biophysics, Warsaw, Poland. Four $\mu$ l of the DNA-extract were added to the PCR mix. The amplification was carried out with initial denaturation at $95^{\circ} \mathrm{C}$ for $10 \mathrm{~min}$, followed by 35 cycles of one denaturation step at $94^{\circ} \mathrm{C}$ for $50 \mathrm{sec}$, primer annealing at $56^{\circ} \mathrm{C}$ for $45 \mathrm{sec}$ and primer extension at $72^{\circ} \mathrm{C}$ for $50 \mathrm{sec}$ in a MJ Research thermocycler (MJ Research, Waltham, USA). A final extension cycle was 10 min at $72^{\circ} \mathrm{C}$. PCR-products were purified using the Gen Elute ${ }^{T M} P C R$ Clean-up kit (Sigma, Japan) according to the manufacturers' instructions.

Amplified products were separated and visualized in $2 \%$ agarose gels $(10 \times 10-\mathrm{cm})$ stained with ethidium bromide, with Tris-borate $(0.089 \mathrm{M}$ Tris, $0.089 \mathrm{M}$ borate, $2 \mathrm{mM}$ EDTA, $\mathrm{pH}$ 8.3) tank and gel buffers. An additional molecular-weight marker 1444-80 pUC/Bsp R1/ Taq (Polgen, Lodz, Poland) was added in the outside lane. The product of SRY fragment amplification was $131 \mathrm{bp}$ in length.

\section{Acknowledgements}

The authors are grateful to Professor Roman Niznikowski from The Department of Sheep and Goat Breeding, Agricultural University in Warsaw, for his expertise on Polish Merino flocks in Poland. This work has been founded by the Council of Scientific Research as an ordered project No PBZ-KBN-084/P06/2002 "Developmental potency of ovine somatic cells introduced into blastocysts".

\section{References}

BASSAM, B.J., BENTLEY, S. (1994). DNA fingerprinting using arbitrary primer technology (APT): a tool or a torment. Australas. Biotechnol. 4: 232-236.

BEATTY, E.M., DOXELY, D.L., FITZSIMONS, J. (1983). Glucosephosphate isomerase polymorphism in sheep. Anim. Blood Groups and Bioechem. Genet. 14: 213-218.

BEDDINGTON, R.S., and ROBERTSON, E.J. (1989). An assessment of the developmental potential of embryonic stem cells in the midgestation mouse embryo. Development 105: 733-737.

BOEDIONO, A., SUZUKI, T., LI, L.Y., GODKE, R.A. (1999). Offspring born from chimaeras reconstructed from parthenogenetic and in vitro fertilized bovine embryos. Mol. Reprod. Dev. 53: 159-70.

BODO, S., GOCZA, E., REVAY, T., HIRIPI, L., CARSTEA, B., KOVACS, A., BODROGI, L., BOSZE, Z. (2004). Production of transgenic chimaeric rabbits and transmission of the transgene through the germline. Mol. Reprod. Dev. 68: 435-40.

BRINSTER, R.L. (1974). The effect of cells transferred into the mouse blastocyst on subsequent development. J. Exp. Medicine 140: 1049-1056.

BUTLER, J.E., ANDERSON, G.B., BONDURANT, R.H., PASHEN, R.L., PENEDO, M.C.T. (1987). Production of ovine chimaeras by inner cell mass transplantation. J. Anim. Sci. 65: 317-324

CHAPMAN, V.M., ANSELL, J.D., MCLAREN, A. (1972). Trophoblast giant cell differentiation in the mouse: expression of glucose phosphate isomerase (GPI1) electrophoretic variants in transferred and chimaeric embryos. Dev. Biol. 29: 48-54.

CIBELLI, J.B., STICE, S.L., GOLUEKE, P.J., KANE, J.J., JERRY, J., BLACKWELL, C., PONCE DE LEON, F.A., ROBL, J.M. (1998). Transgenic bovine chimaeric offspring produced from somatic cell-derived stem-like cells. Nat. Biotechnol. 16: 642-646.

CLARKE, D.L., JOHANSSON, C.B., WILBERTZ, J., VERESS, B., NILSSON, E., KALSTROM, H., LENDAHL, U., FRIESEN, J. (2000). Generalized potential of adult neural stem cells. Science 288: 1660-1663.

CUSHWA, W.T., DODDS, K.G., CRAWFORD, A.M., MEDRANO, J.F. (1996). Identification and genetic mapping of random amplified polymorphic DNA (RAPD) markers to the sheep genome. Mamm. Gen. 7: 580-585.

DUSZEWSKA, A.M., REKLEWSKI, Z., PIENKOWSKI, M., KARASIEWICZ, J.,
MODLINSKI, J.A. (2000). Development of bovine embryos on Vero/BRL cell monolayers (mixed co-culture). Theriogenology 54: 1239-1247.

FEHILLY, C.B., WILLADSEN, S.M., TUCKER, E.M. (1984). Experimental chimaerism in sheep. J. Reprod. Fertil. 70: 347-51.

FEDOROV, L.M., HAEGEL-KRONENBERGER, H., HIRCHENHAIN, J. (1997). A comparison of the germline potential of differently aged ES cell lines and their transfected descendants. Transgenic Res. 6: 223-31.

GEARHART, J.D., MINTZ, B. (1972a). Glucose phosphate isomerase subunitreassociation tests for maternal-foetal and foetal-foetal cell fusion in the mouse placenta. Dev. Biol. 29: 55-64.

GEARHART, J.D. and MINTZ, B. (1972b). Clonal origins of somites and their muscle derivatives: evidence from allophenic mice. Dev. Biol. 29: 27-37.

GEIGER, H., SICK, S., BONIFER, C., MUELLER, A.M. (1998). Globin gene expression is reprogrammed in chimaeras generated by injection adult hematopoietic stem cells into mouse blastocysts. Cel/93: 1055-1065.

HADRYS, H., BALICK, M., SCHIERWATER, B. (1992). Applications of random amplified polymorphic DNA (RAPD) in molecular ecology. Mol. Ecol. 1: 55-63

HUFF, D.R., PEAKALL, R., SMOUSE, P.E. (1993). RAPD variation within and among natural populations of out-crossing bufalograss [Buchloee dactyloides (Nutt.) Engelm.]. Theor. Appl. Genet. 86: 927-934.

IWASAKI, S., CAMPBELL, K.H., GALLI, C., AKIYAMA, K. (2000). Production of live calves derived from embryonic stem-like cells aggregated with tetraploid embryos. Biol. Reprod. 62: 470-5

JASZCZAK, K., PARADA, R., GUSZKIEWICZ, A. (1999). Cytogenetic study of some tissues and age-related changes in cell proportions in a goat-sheep chimera. Cytogenet. Cell Genet. 84: 55-7.

JEFFREYS, A.J., MORTON, D.B. (1987). DNA fingerprints of dogs and cats. Animal Genet. 18: 1-15

JIANG, Y., JAHAGIRDAR, B.N., REINHARDT, R.L., SCHWARTZ, R., KEENE, C.D., ORTIZ-GONZALEZ, X.R., REYES, M., LENVIK, T., LUND, T., BLACKSTAD, M., DU, J., ALDRICH, S., LISBERG, A., LOW, W.C. (2002). Pluripotency of mesenchymal stem cells derived from adult marrow. Nature 418, 41-49.

KARASIEWICZ, J., SZABLISTY, E., GUSZKIEWICZ, A., KOSSAKOWSKI, M., STEFANSKI, G., REED, M., MODLINSKI, J.A. (1996). Development of isolated sheep inner cell masses/embryonic discs in vitro. Roux's Arch. Dev. Biol. 205: 437-442.

KUES, W.A., PETERSEN, B., MYSEGADES, W., CARNWATH, J.W., NIEMANN, $H$. (2005). Isolation of murine and porcine foetal stem cells from somatic tissue. Biol. Reprod. 72: 1020-1028.

LARSON, J.S., YIN, M., FISCHER, J.M., STRINGER, S.L., STRINGER, J.R. (2006). Expression and loss of alleles in cultured mouse embryonic fibroblasts and stem cells carrying allelic fluorescent protein genes. BMC Mol. Biol. 7: 3650.

MACPHERSON, J.M., ECKSTEIN, P.E., SCOLES, G.J., GAJADHAR, A.A. (1993). Variability of the random amplified polymorphic DNA assay among thermal cyclers, and effects of primer and DNA concentration. Mol. Cell. Probes 7: 293299.

MINTZ, B. (1962). Formation of genotypically mosaic mouse embryos. Am. Zool. 2: 432

MODLINSKI, J.A., REED, M.A., WAGNER, T.E., KARASIEWICZ, J. (1996). Embryonic stem cells: developmental capabilities and their possible use in mammalian embryo cloning. Anim. Reprod. Sci. 42: 437-446.

NOTARIANNI, E., LAURIE, S., NG, A., SATHASIVAM, K. (1997). Incorporation of cultured embryonic cells into transgenic and chimeric, porcine fetuses. Int. J. Dev. Biol. 41: 537-40.

ONISHI, A., TAKEDA, K., AKITA, T., HANADA, H. (2000). Production of chimaeric pigs by injection of primary cultured inner cell mass cells. Theriogenology 53: 237.

PILISZEK, A., MODLINSKI, J.A., PYSNIAK, K., KARASIEWICZ, J. (2007). Foetal fibroblasts introduced to cleaving mouse embryos contribute to full-term development. Reproduction 133: 207-218.

RAO, K.B.C., BHAT, K.V., TOTEY, S.M. (1996). Detection of species-specific genetic markers in farm animals through random amplified polymorphic DNA (RAPD). Genet. Anal. 13: 135-138. 
RASERO, R., DI STASIO, L., BERRA, G.P. (1993). Polymorphism of erythrocyte glucosephosphate isomerase in sheep. Anim. Genet. 24: 63-64.

RHO, G-J., KANG, T-Y., KOCCHAR, H.P.S., HAHNEL, A.C., BETTERIDGE, K.J. (2001). Effects of blastomere sex and fluorescent labelling on the development of bovine chimaeric embryos reconstituted at four-cell stage. Mol. Reprod. Dev. 60: 202-207.

ROBERTSON, E.J. (1987). Embryo derived stem cell lines, In: Teratocarcinomas and embryonic stem cells. A practical approach (Ed. E.J.Robertson), IRL Press, Oxford, Washingon DC, pp 71-112.

SAITO, S., SAWAI, K., UGAI, H., MORIYASU, S., MINAMIHASHI, A., YAMAMOTO, Y., HIRAYAMA, H., KAGEYAMA, S., PAN, J., MURATA, T., KOBAYASHI, Y., OBATA, Y., YOKOYAMA, K.K. (2003). Generation of cloned calves and transgenic chimaeric embryos from bovine embryonic stem-like cells. Biochem. Biophys. Res. Commun. 309: 104-13.

SCHOONJANS, L., ALBRIGHT, G.M., LI, J.L., COLLEN, D., MOREADITH, R.W. (1996). Pluripotential rabbit embryonic stem (ES) cells are capable of forming overt coat color chimeras following injection into blastocysts. Mol. Reprod. Dev. 45: 439-43.

SUWINSKA, A., OZDZENSKI, W., WAKSMUNDZKA, M., TARKOWSKI, A.K. (2005). Experimentally produced diploid-triploid mouse chimaeras develop up to adulthood. Mol. Reprod. Dev. 72: 362-76.
TAKAHASHI, K., YAMANAKA, S. (2006). Induction of pluripotent stem cells from mouse embryonic and adult fibroblast cultures by defined factors. Ce//126: 663 76.

TARKOWSKI, A.K. (1961). Mouse chimaeras developed from fused eggs. Nature 190: 857-860

TARKOWSKI, A.K., OZDZENSKI, W., CZOLOWSKA, R. (2001). Mouse singletons and twins developed from isolated diploid blastomeres supported with tetraploid blastomeres. Int. J. Dev. Biol. 45: 591-596.

TUCKER, E.M., MOOR, R.M., ROWSON, L.E. (1974). Tetraparental sheep chimaeras induced by blastomere transplantation. Immunology 26: 613-21.

WANG, Z.Q., Kiefer, F., Urbanek, P., Wagner, E.F. (1997) Generation of completely embryonic stem cell-derived mutant mice using tetraploid blastocyst injection. Mech. Develop. 62: 137-145.

WEST, J.D., Flockhart, J.H. (1994). Genotypically unbalanced diploid-diploid foetal mouse chimaeras: possible relevance to human confined mosaicism. Genet. Res. 63: 87-99. Erratum in: Genet. Res. (1994) 63:†236.

WILLIAMS, J., Kubelik, A., Livak, K., Rafalski, J.A., Tingey, S. (1990). DNA polymorphisms amplified by arbitrary primers are useful as genetic markers. Nucleic Acids Res. 18: 6531-6535.

\section{Related, previously published Int. J. Dev. Biol. articles}

See our recent Special Issue Developmental Biology in Poland edited by Kloc, Maleszewski and Tarkowski at:

http://www.ijdb.ehu.es/web/contents.php?vol=52\&issue=2-3

See our Special Issue Mammalian Reproduction \& Development in honor of Anne McLaren and edited by Brigid Hogan at:

http://www.ijdb.ehu.es/web/contents.php?vol=45\&issue $=3$

Mouse chimaeras developed from electrofused blastocysts: new evidence for developmental plasticity of the inner cell mass

Andrzej K. Tarkowski, Kamila Jagiello, Renata Czolowska and Waclaw Ozdzenski Int. J. Dev. Biol. (2005) 49: 909-914

\section{Vasculogenesis and angiogenesis in the mouse embryo studied using quail/mouse chimeras}

Michel Pudliszewski and Luc Pardanaud

Int. J. Dev. Biol. (2005) 49: 355-361

\section{Mouse-chick neural chimeras}

Josiane Fontaine-Pérus and Yvonnick Chéraud

Int. J. Dev. Biol. (2005) 49: 349-353

Developmental potential of mouse tetraploid cells in diploid <--> tetraploid chimeric embryos.

Yuji Goto, Junko Matsui and Nobuo Takagi

Int. J. Dev. Biol. (2002) 46: 741-745

Chimaeras and mosaics for dissecting complex mutant phenotypes.

A Nagy and J Rossant

Int. J. Dev. Biol. (2001) 45: 577-582

How many blastomeres of the 4-cell embryo contribute cells to the mouse body? A K Tarkowski, W Ozdzenski and R Czolowska Int. J. Dev. Biol. (2001) 45: 811-816

Morphological chimeras of larvae and adults in a hydrozoan--insights into the control of pattern formation and morphogenesis.

$M$ Kroiher

Int. J. Dev. Biol. (2000) 44: 861-866

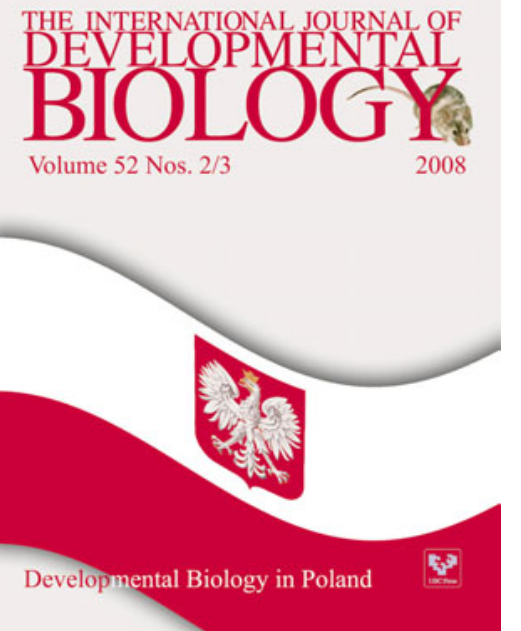

2006 ISI ${ }^{\star \star}$ Impact Factor $=3.577^{\star \star}$

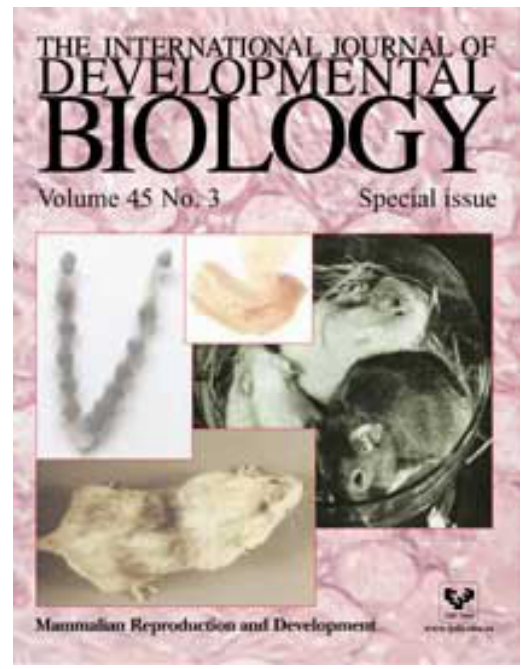

